\title{
PRINCIPAL-AGENT PREFERENCES IN IMPERFECT MARKETS: THEORETICAL ANALYSIS ON MURABAHAH AND IJARAH
}

\author{
Hechem Ajmi ${ }^{1}$, Hassanuddeen Abdul Aziz ${ }^{2}$, Salina Kassim ${ }^{3}$ and Walid Mansour ${ }^{4}$ \\ ${ }^{1}$ International Islamic University Malaysia (IIUM), Malaysia, hechemajmi@gmail.com \\ ${ }^{2}$ International Islamic University Malaysia (IIUM), Malaysia, ksalina@iium.edu.my \\ ${ }^{3}$ International Islamic University Malaysia (IIUM), Malaysia, ahassan@iium.edu.my \\ ${ }^{4}$ Saudi Arabian Monetary Authority, Saudi Arabia, wmansour@sama.gov.sa
}

\begin{abstract}
This paper aims to determine the optimal contract for the principal and the agent in imperfect markets, when murabahah and ijarah are used. The financial contracting enforceability approach is employed to determine the contract that maximizes the value of the firm subject to agents' constraints when the shock is low and high, and regarding market frictions. Furthermore, this approach allows us to assess the level of market frictions that agents may bear in case of low shock and high shocks. Findings reveal that the simulated values of the market frictions' parameters for both contracts increase when moving from the low shock to the high shock. Such evidence implies that the agent is more likely to cheat and hide significant information about the project when the shock is high. As a response to this higher risk, the simulated values of the profit margin parameters for the principal rise also when the shock is high in order to compensate for the increase of market frictions and mitigate conflicts of interest. By comparing both contracts based on the simulated optimal values of the firm, it is noticeable that the gap between both contracts is very tight, which can be attributed to their common debt-based financial arrangements. However, the results show that ijarah allows the principal and the agent to generate the highest value in case of low shock and high shock, comparing to murabahah. Therefore, ijarah seems to be more attractive for the principal and the agent than murabahah.
\end{abstract}

Keyword: Murabahah, Ijarah, Conflict of Interest, Monte-Carlo Simulation, Market Frictions. JEL Classification: C61; G14; G23; L24; L25.

Article history:

Received : October 16, 2018

Revised : March 04, 2019

Accepted : March 05, 2019

Available online : March 15, 2019

https://doi.org/10.21098/jimf.v5i1.1050 


\section{INTRODUCTION}

This paper puts stress on conflicts of interest among agents when murabahah and ijarah financings are used. Indeed, IFSB ${ }^{1}$ announced that murabahah is the most used contract by Islamic financial institutions instead of ijarah and other debt-contracts. However, there is no theoretical or empirical proof to explain the reasons behind the excessive use of murabahah in Islamic finance from the financial perspective. Indeed, the financial contracting literature focused on profit-and loss sharing contracts because they entail more moral hazard and information asymmetry problem comparing to debt financings. Nevertheless, the practice showed that market frictions might also occur in case of debt contracts, due to the misuse of the asset (Ebrahim and Sheikh, 2016). In lack of insights in the literature, this paper aims to determine the optimal contract that maximizes the value of the firm and handle conflicts of interests ${ }^{2}$ between the principal and the agent when market frictions occur.

To do so, this paper opts for the financial contracting enforceability approach based on the study of Cooley et al (2004) and Monte-Carlo simulation to assess the optimal contract for the principal and the agent between murabahah and ijarah. This approach aims to determine the optimal contract that maximizes the value of the firm subject to the enforcement constraint for the agent (the entrepreneur) and participation constraint for the principal (the financier) when the industrial shock is low and high, and regarding market frictions. Based on the studies of (Tauchen, 1986; Adda and Cooper, 2002) the low and high shocks follow a firstorder Markov process, which implies that the value of the high shock depends on the low shock value. Similarly, the financial contracting enforceability approach allows us to assess the level of market frictions that agents can bear in the case of low shock and high shock for murabahah and ijarah financings.

In sum, the financial contracting enforceability approach enables us to determine the optimal contract that aligns agents' interests. In addition, it allows us to assess the level of market frictions that the principal and the agent may bear when the shock is low and high for murabahah and ijarah financings. To achieve this purpose, section two discusses the most relevant studies in the conventional and Islamic literature. Section three highlights the methodology adopted, the different equations and models linked to each contract and the assumptions. Section four considers the parameters calibration. Section five presents the simulation results. Finally, section six concludes.

\section{LITERATURE REVIEW}

\subsection{Financial Contracting Theory from The Conventional Perspective}

Contractual arrangements have been widely treated in the conventional literature. Starting from Smith (1776) some incentive issues linked to sharecropping contracts have been determined, which are profit-and loss sharing, monitoring process and

1. See Islamic Financial Services Board (IFSB), (2018), Financing by Type of Shari'ah Compliant Contract, https://www.ifsb.org/psifi_02.php

2. See Hart and Moore (1992); Aghion et al., (1992) Hart (2017) for the examination of conflicts of interest in the incomplete contract theory 
adverse selection in human cooperation. To mitigate these issues, Coase (1973) highlighted a new theory to assess the performance of the firm by putting stress on the role of technology and return to scale, as important determinants of the size of the firm and the optimal production. Nevertheless, the author considered the firm as a black box and completely ignored incentive problems within it (Hart, 1995). This theory was later extended by Williamson (1979) and Jensen and Meckling (1976) and became known as the economics of organization. The authors established the agency theory that considers the effect of the manager and the selfish behavior of agents to assess the contractual relationship when moral hazard and asymmetric information occur. However, the agency approach falls foul of the same criticism because it did not say much about the internal organization of the firm (Hart,1995). An alternative approach to address the issues in incomplete contract proposed that the cornerstone of the incomplete contract theory is the allocation of decision rights ${ }^{3}$, which later was extended to include the roles of bargaining power in order to align the interests of agents. Hart and Moore (1994) showed that careful allocation of decision rights could substitute the contractually specified rewards. Accordingly, this approach has been developed based on important conditions: (i) the principal is risk-neutral; (ii) there is only one principal and one agent; and (iii) the agents have symmetric information ex-ante. The assumption that agents do not face asymmetric information ${ }^{4}$ problem ex-ante is a rather strong assumption to make. Consequently, it is difficult to admit the first and third conditions in our study as in real practice financiers cannot be riskneutral. In addition, information asymmetry ${ }^{5}$ represents the main determinant of any investment decision. In sum, we argue that financial contracting theory and incomplete contract approach have brought relevant solutions for decisions and rights control, with further insights and procedures must be implemented regarding conflicts of interest between agents.

\subsection{Financial Contracting Theory from The Islamic Perspective 2.2.1. Islamic Equity-Based Contracts}

The financial contracting theory has also been explored from the Islamic perspective, with particular focus given to the notion of profit-and loss sharing (PLS), alongside the moral hazard and asymmetric information problems. However, the literature was divided into two mainstreams where the first justifies the marginalization of PLS-based contracts, whereas the second encourages their adoption.

Among those who justified the marginalization of PLS contracts, Dar and Presley (2000), Farooq (2007), and Ebrahim and Sheikh (2016) assumed that an imbalance between management and control rights is attributed as a major cause of lack of PLS in the practice of Islamic finance. Given this imbalance, the agency

3. See Hart (1989), Hart (2003), Hart (2017) for the examination of allocation of decision rights in the incomplete contract theory

4. See Ross (1973); Arrow (1971); Jensen and Meckling (1976); Akerlof (1970) and Tirole, (1999) for a theoretical understanding of moral hazard and information asymmetry in contractual arrangements.

5. See Chichti and Mansour (2010-a, 2010-b, 2012) and Mansour (2014) for a theoretical background on information asymmetry. 
problem becomes severer, which renders the PLS principle less attractive vis-àvis other modes of financing, which is in line with the studies of (Muhammad, 2014; Lone and Quadir, 2017). To this extent, Al-Suwailem (1998) proposed venture capital as a potential model of musharakah. However, the author did not provide relevant evidence about the relationship between venture capital model and the Islamic model of partnership regarding moral hazard and asymmetric information problem. The recent study of Mehri et al. (2017) proposed a theory of profit-sharing ratio with information asymmetry and considered the negotiated profit-sharing ratio (PSR) as a screening device in their framework. Although this theoretical framework constitutes a new tool for the screening managers' type, the authors found that adverse selection can be captured when the (PSR) accepted by the manager exceeds a given threshold value, which represents the maximum payoff to the venture capitalist.

Among those who encouraged the adoption of PLS agreement, Muda and Ismail, (2010) and Sapuan (2016) proposed optimal conditions to minimize the problem of asymmetric information, such as providing incentives for entrepreneurs in case of profit and the establishment of monitoring device for musharakah. In the same context, Ernawati (2016) analyzed the risk of PLS financing in Indonesian Islamic banking. The author showed that it is more secure for Islamic banks to allocate funds in musharakah contracts instead of mudarabah.

In line with the aforementioned studies, Nabi (2012) examined the effect of PLS contract on the evolution of the income inequality with capital accumulation process based on the study by Aghion and Bolton (1997). Nabi (2012) treated the problem of wealth inequality between two investors with different wealth classes. He found that the wealth inequality between the two classes of investors decreases over time, which proves that the PLS contract changes the dynamic of wealth. This evidence implies that the entrepreneurship allows the latter to catch-up the initially wealth class, which is in line with the study of Maghrebi and Mirakhor (2015).

Based on the agency issues related to equity-based contracts, 6 Mansour et al. (2015-b) proposed a new equity-based instrument through a three-tier partnership by including a new contracting party defined as the risk moderator in order to absorb the underlying risk of default and adjust the annual revenue to a predetermined annual cost. Interestingly, the simulation results show that immunization against premature default through the involvement of the risk moderator to absorb any potential loss is indicative of an incentive factor for the project's survival and business continuity. Al-Suwailem (2003) examined the optimal sharing contracts by comparing the PLS contract to the standard debt contract (involving riba), under the cases of symmetric and asymmetric information. It is found that the aggregate expected profits from the sharing contract exceed those of the debt contract, under both symmetric and asymmetric information. Moreover, for a certain range of the opportunity cost both the financier and the agent are better off when they get involved in a sharing contract instead of debt contract.

6. See Majdoub et al. (2014, 2016, 2018), Bedoui and Mansour (2015), and Mansour et al. (2015-a) for an examination of the theoretical foundation of equity-based contracts. 
Ahmed (2002) came up with a theoretical framework for PLS financing contracts based on the study by Gale and Hellwing (1985), with the aim of determining the incentive-compatible contracts. While banks do not mostly have the incentive to enforce PLS contracts, Ahmed (2002) provided several incentives to bankers and entrepreneurs to proceed with this financing contract. The author asserted that the specification of the profit share, the adverse selection analysis, the auditing rule, and the reward/punishment rules are fundamental to build a strong partnership in imperfect markets.

\subsubsection{Islamic Debt-Based Contracts}

As far as PLS contracts are concerned, the literature has not widely explored debt contracts such as murabahah and ijarah financings from the principal-agent point of view. A particular focus was given to shari'ah, and legal aspects. Nevertheless, the financial issues have been forgotten except for the examination of murabahah home financing ${ }^{7}$. Concerning murabahah ${ }^{8}$ financing, the studies of Ustani (2013), Cahyono (2011), and Shofawati (2014), among others, examined the figh and regulation from Shariah Board for murabahah financing in Indonesia. The authors discussed the practice of murabahah financing in Indonesia using a descriptive qualitative method. As a result, they found that the implementation of murabahah financing in Islamic Banking in Indonesia could fulfill shariah requirements with fatwa from National Shariah Council in Indonesia9.

Dealing with ijarah financing, the same aspects have been treated, whereas some studies examined ijarah from the financial point of view in the case of vehicle and house financings. For instance, Al-Mubarak and Badri, (2015), examined the ijarah contract from the shari'ah perspective with the aim to determine how a diligent compliance to its maqasid can help managing shari'ah and business risks. In their study, the authors assumed that a sincere compliance to the shari'ah's objectives in financial transaction would reduce risks in the Islamic banking industry. Current applications of ijarah by Islamic banks in Malaysia were assessed in order to identify the gaps between its theoretical presumptions and actual applications. Similarly, the authors discussed some unresolved shari'ah issues relating to the implementation of ijarah thumma al-bay (AITAB) (a contract of leasing ending with a sale) in order to provide evidence for such dissonances. Consequently, the authors shed some lights on the need to undertake constructive measures by policy makers to resolve the governance and legal problems with regard to the implementation of AITAB.

The latest study by Hanif (2016) examined legal forms and economic substance of several Islamic contracts used by the Islamic financial industry namely, murabahah, ijarah, musharakah and mudarabah. Findings reveal that the legal form of the contracts are in line with the theory of Islamic financial system. However,

7. See Aris et al (2012), Khan et al (2015), Hashmi and Omar (2009), and Khong et al (2018) for the examination of murabahah home financing.

8. See Buchori, et al. (2004) and Ascarya (2007) for the theoretical understanding for the main characteristics of murabahah in classical literature and practice in Indonesia.

9. See Fatwa Dewan Syari'ah Nasional No: 04/DSN-MUI/IV/2000 on Murabahah. 
economic substance is considered similar to the conventional counter parts. In the same context, Abdullah (2016) examined three Islamic contracts approved by US authorities namely, musharakah, murabahah and ijarah in order to determine whether they are acting in the public interest. The author adopted qualitative document and content analysis, supported by quantitative numerical analysis, in reviewing legal interpretive letters from the US Office of the Comptroller of Currency and National Administrator of Banks (OCC) and the US Department of Revenue. Although the Americans adopted economic substance over legal form, Abdullah (2016) applied the Islamic normative theory of profit to test their conclusions. Consequently, it is found that in assessing economic substance over legal form, each of the three contracts involved risk-free transaction and interest.

Chhapra et al, (2018) analyzed consumers' preference and awareness when conventional and Islamic ijarah auto financing are used in Pakistan. Findings indicated that convenience is the main determinant for preference of Ijarah over the lease contract. In addition, all other factors besides religion namely, consumer's awareness and income have a positive impact on consumers' preference. Thereby, the authors indicated that in Pakistan, religion is not the only fact motivates individuals to consider ijarah financing.

In the same context, the recent study by Wahla et al., (2018) measured customers' perception of car ijarah financing services provided by the Islamic banks and financial institutions in Pakistan. The authors adopted two research methodologies namely Kruskal-Wallis and Mann-Whitney test (non-parametric) and logit regression model (parametric). Both methods were applied to a real data set of 300 respondents from various cities of Pakistan in the car ijarah financing industry. The demographic effects were also considered to determine the perception about the degree of shari'ah compliance and the quality of service of transaction offered by banks. It is found that the customers who used the car ijarah facility from Islamic banks have positive attitude toward this sort of transaction. In addition, gender, income, and marital status affect the perception about the quality of shari'ah compliance. Moreover, the quality of service of transaction issues is very important to selected clients in the industry.

Based on the existing studies in the field, too much emphasis on shari'ah and legal issues was noticed, whereas the principal-agent relationship has been forgotten. In this regards, further insights are needed with the aim to provide explanations regarding the principal-agent problem in the case of ijarah financing.

\subsection{Gaps in The Literature}

The conventional literature in contractual arrangement came out with relevant insights regarding the principal-agent problem. Nevertheless, it is shown that the hypothesis related to the principal's risk neutrality and the symmetric information ex-ante are hard to be satisfied due to the existence of market frictions in financial contracting. Therefore, an alternative approach is needed with the aim to consider the interests of the principal and the agent for seeking the optimal contract in imperfect market. In the same context, the Islamic studies in contractual arrangement have shown too much emphasis on legal and shari'ah aspects of 
the financial contracting in the case of debt financing, and they have not given consistent evidence about the principal-agent relationship in imperfect market.

In lack of insights regarding Islamic debt-financings this paper highlights the financial contracting enforceability approach in order to determine the optimal contract that maximizes the value of the firm in the first hand and aligns agents' interests in the second hand, when murabahah and ijarah financings are used. In the same context, this approach enables us to assess the level of market frictions that agents may bear if they want to maximize their profit when the industrial shock is low and high. Specifically, with the excessive use of murabahah instead of ijarah, the literature has not provided relevant empirical or theoretical evidence to explain this feature. Accordingly, this paper considers the financial contracting enforceability approach and Monte-Carlo simulation with the aim to yield additional proof regarding the selection of the most attractive contract for the principal and the agents among murabahah and ijarah.

\section{MODEL DESIGN}

\subsection{Understanding the Financial Contracting Enforceability Approach and Its Application in Contractual Arrangement}

Financial contracting enforceability is defined as the ability of each part to repudiate the contract for a given reason ${ }^{10}$. It has been employed in several contexts, such as the examination of the risk of repudiation in case of limited liability ${ }^{11}$ and the relationship between debt-constrained and asset markets ${ }^{12}$. Other areas were explored such as contractual imperfections for international differences in the organization of production ${ }^{13}$, and the treatment of the optimal lending contracts with imperfect enforceability ${ }^{14}$. In contractual arrangement, Cooley et al., (2004) examined a general equilibrium model in which agents and principals enter into a long-term contractual relationship, subject to enforceability constraints. Theoretically, their method is closely linked to the partial equilibrium model of Marcet \& Marimon (1992) with two relevant differences.

First, Cooley et al., (2004) run the analysis in a general equilibrium framework. Second, they do not assume that repudiation leads to market exclusion. Once the contract has been signed, the firm has the ability to start a new investment project by accepting a new contractual relationship, while the repudiation value is endogenous and depends on all the general equilibrium conditions.

If defaulting entrepreneurs are not excluded from the market, firms can start a new project by entering into a new contractual relationship, while the higher value

10. See Cooley et al., (2004) for the theoretical understanding of the financial contracting enforceability approach and its application in contractual arrangement.

11. See Atkeson (1991) for the examination of the risk of repudiation in case of limited liability.

12. See Kehoe and Levine (1993) for the examination of the relationship between debt-constrained and asset markets.

13. See Quintin (2003) for the application of the financial contracting enforceability approach in contractual imperfections for international differences in the organization of production.

14. See Albuquerque and Hopenhayn (2004) for the application of the financial contracting enforceability approach to determine the optimal lending contracts with imperfect enforceability. 
of the new project makes the repudiation option more attractive. However, to prevent repudiation, the value of the contract for the entrepreneur must increase. In other words, Cooley et al., (2004) assumed that when this value is increased, the tightness of the enforcement constraint is relaxed and more capital is given to the firm. Although the aforementioned studies considered the financial contracting enforceability approach for different purposes, they all considered market frictions as the cornerstone of the optimal financing contract determination, comparing to the hypothesis linked to the incomplete contract theory that we have discussed previously.

Drawn upon the study of Cooley et al., (2004), the optimal contract must maximize the value of the firm subject to two constraints, which are the enforcement constraint for the agent and the participation constraint for the principal. The first constraint shows that the agent (the firm) may accept to enforce the contract when the expected profit generated exceeds the default value. This default value is an endogenous function, depending on the capital invested, and the industrial shocks affecting the profit of the firm. The second constraint implies that the expected profit share for the principal (the financier) must be greater or equal to the set-up investment. Otherwise, the contract will not be executed. Based on the financial contracting enforceability approach proposed by Cooley et al., (2004) among others, we are able to determine the contract that maximizes the value of the firm and aligns agent's interest in case of imperfect market. By comparing to the previous studies in Islamic and conventional finance, this approach allows us to determine the optimality of equity and debt financings based on the interests of the principal and the agent. In addition, it enables us to assess the level of market frictions that the principal and the agent may bear, if they want to maximize their profit. In sum, this method allows us to deal with contractual arrangements from a new angle with the aim to come out with relevant insights regarding conflicts interest mitigation in imperfect market.

\subsection{General form of the maximization program}

Consider $X_{t}$ the payments received by the entrepreneur at time $t$, the maximization program based on Cooley et al (2004) is the following:

$\max V_{t}\left(F_{t}, Z\right)=E_{t} \sum_{t=1}^{T} \beta^{t} X_{t}$

Subject to

$$
\begin{aligned}
& E_{\mathrm{a}} \sum_{t=1}^{T} \beta^{t} X_{t} \geq D_{t} \\
& D_{t}=\bar{V}_{t}-\kappa \\
& \bar{V}_{t}=(1-p) V_{t}\left(F_{t}, z_{L}\right)+p V_{t}\left(F_{t}, z_{H}\right) \\
& E_{t} \sum_{t=1}^{T} \beta^{t} Y_{t} \geq I_{0}
\end{aligned}
$$


Equation (1) defines the value of the firm, which depends on the profit generated by the firm " $X t$ " the maturity of the contract $T$, which is equal to 5 years, the total fund invested " $F t^{\prime \prime}$, the labor parameter $l t$ and the discount rate factor. Furthermore, the variable $Z=\left[Z_{L}, Z_{H}\right]$ presents the industrial shocks which could be low or high. According to Tauchen (1986), these shocks follow a first order Markov process because the value of the shock in the future depends on the previous or actual value. As mentioned by Adda and Cooper (2002) the probability of fulfilling $Z_{H}$ depends on the current value of the shock which is $Z_{L}$.

Equation (2) is the enforcement constraint, where the first component defines the profit received by the agent (the entrepreneur) and the second component refers to the default value or the repudiation value. According to Cooley et al (2004) the value of continuing the contract for the firm after realization of the shock cannot be smaller than the value of repudiation. More precisely, the authors indicated that the firm shall continue the project only if the enforcement value is greater than the default value. As pointed out by the same authors, the default value has been defined in equation (3), where $\bar{V}_{t}$ are $\kappa$ respectively, the value of searching a new project and the cost of repudiation. Similarly, Cooley et al (2004) claimed that the value of searching a new project is endogenous and depends on all the equilibrium conditions. In addition, they imply that the variable $p$ in the equation (4) refers to the probability of finding the high productivity project, which depends on the availability of the projects and on the number of searching entrepreneurs. Therefore, they assume that $p=\min \left\{\frac{\mathrm{M}}{\mathrm{S}}, 1\right\}$ where $\mathrm{M}$ refers to the available projects and $S$ defines the number of searching entrepreneurs. Cooley et al (2004) measured this probability according to how the economy responds to the arrival of a new technology that increases the number of high-productivity projects $M$.

Cooley et al (2004) considered two assumptions about the persistence of the shock, which are temporary and permanent. However, we should mention that in our study the persistence of the industrial shock cannot be permanent because the economy has always been changing. Concerning the situation of temporary shocks, they consider the case in which $M_{t}$ is independently and identically distributed as uniform in the interval $[0, n]$ where $n$ is the mass of newborn entrepreneurs. Thus, the expected value of $M_{t}$ is defined by $\bar{M}=n / 2$. Although in equilibrium only new-born entrepreneurs search for a high-productivity project, Cooley et al (2004) claim that $S_{t}=n$, and the probability of success $p=M_{t} / n$ is uniformly distributed in the interval $[0,1]$. In the same way, Cooley et al (2004) showed that after a long sequence of $M_{t}=\bar{M}$, the arrival of a new technology increases $M_{t}$ to $2 \bar{M}=n$. Hence, this implies that after a long sequence of $p_{t}=0,5$, this probability increases to one then it reverts to its mean value after the next period. Although $p=\min \left\{\frac{\mathrm{M}}{\mathrm{s}}, 1\right\}$, $\bar{M}=v / 2$ and $S_{t}=n$ in equilibrium, the expression of the probability of finding the high productivity project will be defined as given: $p=\min \left\{\frac{n}{n}, 1\right\}$. More precisely it will be equal to $p=\min \left\{\frac{1}{2}, 1\right\}$. Equation (5) is the participation constraint for the principal (the financier), where, $Y_{t}$ is the profit given to the financier and $I_{0}$ is the setup investment. This constraint imposes that the discounted value of payments received by the principal should be equal or greater than the setup investment. Otherwise, the financier may repudiate the contract. 


\subsection{Profit and Cost equations}

This sub-section aims at determining the profit and cost equations for the agent when murabahah and ijarah financing are used. For what follows, Cooley et al (2004) assumed that it is convenient to define the discounted expected profit generated by the firm before determining the profits equations related to both contracts. Accordingly, the profit equation form is provided as follows:

$$
\pi_{t}\left(F_{t}, l_{t}, \omega_{t}, Z\right)=-F_{t}+\left(\frac{1}{1+r_{f}}\right)\left[b F_{t}+(1-b)\left[(1-\delta) F_{t}+f_{t}\left(Z, F_{t}, \alpha\right)-\omega_{t} l_{t}\right]\right](6)
$$

The production function can take two different values:

$$
\begin{aligned}
& f_{t}\left(z_{L}, F_{t}, \alpha\right)=z_{L} F_{t}(1-\alpha) \text { in case of low shock } \\
& f_{t}\left(z_{H}, F_{t}, \alpha\right)=z_{H} F_{t}(1-\alpha) \text { in case of high shock }
\end{aligned}
$$

where the parameter $0<b<1$ is the probability of liquidation that stems from the event of losing the project due to the agent's death or any other unexpected events, (Cooley et al., 2004). The function $f t$ depends on the industrial shock $Z=\left(Z_{L}, Z_{H}\right)$ and the invested funds. The parameter $0<\alpha<1$ measures market frictions. The parameter $0<\delta<1$ is a random variable defining the depreciation rate. Finally, the parameters $\omega_{t}$ and $l_{t}$ represent the wage and the labor respectively.

The profit function of Cooley et al. (2004) takes account of several variables that may affect the production function and the survival of the firm in imperfect markets. They considered that the industrial shocks, the probability of liquidation, the wage and labor are fundamental to assess the profit generated by the firm. If the firm is liquidated, which happens when $b$ reaches the unity, the firm's value is equal to $\frac{-r_{f} F_{t}}{\left(1+r_{f}\right)}<0$. Nevertheless, if the firm does not face any risk of liquidation, i.e., $b=0$, the production takes place and the firm's value is $-F_{t}+\left(\frac{1}{1+r_{f}}\right)\left[(1-\delta) F_{t}+f_{t}\left(Z, F_{t}, b\right)-\omega_{t} l_{t}\right]$. The disutility from working is defined by Cooley et al. (2004) as:

$$
\varrho\left(l_{t}\right)=B l^{(1+\epsilon) / \epsilon},
$$

where $B$ is a factor that captures the amount of time spent on working and $\epsilon$ corresponds to the elasticity of labor. With the properties of the disutility function can be given by the following partial derivatives with respect to labor: $\varrho(0)>0$; $\varrho^{\prime}\left(l_{t}\right)>0$; and $\varrho^{\prime \prime}\left(l_{t}\right)>0$. Cooley et al. (2004) claim that the wage factor is the first derivative of the disutility from working $\omega_{t}=\varrho^{\prime}\left(l_{t}\right)$, implying that $\varrho^{\prime}\left(l_{t}\right)=\omega_{t}=$ $B \frac{1+\epsilon}{\epsilon} l^{(1+\epsilon / \epsilon)-1 .}$ 


\subsubsection{Profit and Cost Functions for Murabahah}

Murabahah contract is defined as a sale transaction used in trade and asset. Generally, the bank purchases the materials and delivers them to the client. Thus, the delivering price is usually increased by a pre-determined rate, which represents the profit of the principal. This rate is mostly negotiable between agents before concluding the contract. Furthermore, the payment is deferred to a date agreed by the two parties. In case of default, however, the agent loses the control of the asset. Consider the parameter $g_{t}$ as the increased pre-determined rate fixed by the principal, the fund raised by the firm in this case will be equal to $F_{t}^{e}(1+g)$, where $g_{t}$ denotes the profit margin for the principal and $F_{t}^{e}=F_{t}$ defines the external fund. Thereby, the profit function of the firm is presented as given:

$$
X_{t}^{\text {mur }}=\pi_{t}\left(F_{t}^{e}\left(1+g_{t}\right), l_{t}, \omega_{t}, Z\right)
$$

Where:

$$
\begin{aligned}
& \pi_{t}\left(F_{t}^{e}\left(1+g_{t}\right), l_{t}, \omega_{t}, Z\right)=-F_{t}^{e}\left(1+g_{t}\right)+\left(\frac{1}{1+r_{f}}\right)\left[b F_{t}^{e}\left(1+g_{t}\right)+(1-b)\right] \\
& {\left[(1-\delta) F_{t}^{e}\left(1+g_{t}\right)+f_{t}\left(Z, F_{t}^{e}\left(1+g_{t}\right), l_{t}, \alpha\right)-\omega_{t} . l_{t}\right]} \\
& f_{t}\left(z_{L}, F_{t}^{e}\left(1+g_{t}\right), \alpha\right)=z_{L}\left(F_{t}^{e}\left(1+g_{t}\right)\right)(1-\alpha) \text { in case of low shock } \\
& f_{t}\left(z_{H}, F_{t}^{e}\left(1+g_{t}\right), \alpha\right)=z_{H}\left(F_{t}^{e}\left(1+g_{t}\right)\right)(1-\alpha) \text { in case of high shock }
\end{aligned}
$$

In the same way, the cost of this contract, which represent the profit received by the principal is defined as given:

$$
Y_{t}^{m u r}=g_{t} F_{t}^{e}
$$

Where, $g_{t}$ defines the remuneration of the principal and $F_{t}^{e}$ is the total funds invested. In case of default, the firm will not be able to repay the loan, which obliges the agent to repudiate the contract and loses the control of the asset.

\subsubsection{Profit and Cost Equations for Ijarah}

According to the literature, ijarah is a contract of sale of right for a period of time, and it takes a hire-purchase form. For example, sometimes there is a promise by the lessor to sell the asset to the lessee (the agent) at the end of the contract, or simply return it to the owner. Thereby, the firm may face two different types of ijarah, namely the operating lease and financial lease, which is also known as Ijarah Muntahia Bittamleek (IMB). In case of operating lease, the ownership of the leased assets remains with the bank at the end of the lease period. Nevertheless, Ijarah Muntahia Bittamleek (IMB) or financial lease is defined as a form of transfer of ownership of assets for a particular period based on a defined rent.

According to shari'ah Authority Council of Bank Negara Malaysia (SAC), this rent is usually higher than the normal rental to encourage the lessor to transfer the leased assets to the lessee at the end of the lease period after the settlement of all installments immediately. In this study thereby, we consider the second form of 
ijarah, while it is considered the most known is Islamic finance as stated by Shari'ah Authority Council of Bank Negara Malaysia (SAC). While ijarah is relatively linked to lease contract, we consider $\phi$ the pre-determined rate increasing funds invested. The parameter $\phi$ defines the profit margin received by the principal in case of financial lease. Consequently, the profit and the cost equations of the firm are defined below:

$$
X_{t}^{i j a}=\pi_{t}\left(F_{t}^{e}\left(1+\varphi_{t}\right), l_{t}, \omega_{t}, Z\right)
$$

Where,

$$
\begin{aligned}
& \pi_{t}\left(F_{t}^{e}\left(1+\varphi_{t}\right), l_{t}, \omega_{t}, Z\right)=-F_{t}^{e}\left(1+\varphi_{t}\right)+\left(\frac{1}{1+r_{f}}\right)\left[b F_{t}^{e}\left(1+\varphi_{t}\right)+(1-b)\right] \\
& {\left[(1-\delta) F_{t}^{e}\left(1+\varphi_{t}\right)+f_{t}\left(Z, F_{t}^{e}\left(1+\varphi_{t}\right), F_{t+1}^{e}\left(1+\varphi_{t}\right), l_{t}\right)-\omega_{t} l_{t}\right]} \\
& f_{t}\left(z_{L}, F_{t}^{e}\left(1+\varphi_{t}\right), \alpha\right)=z_{L}\left(F_{t}^{e}\left(1+\varphi_{t}\right)\right)(1-\alpha) \text { in case of low shock } \\
& f_{t}\left(z_{H}, F_{t}^{e}\left(1+\varphi_{t}\right), \alpha\right)=z_{H}\left(F_{t}^{e}\left(1+\varphi_{t}\right)\right)(1-\alpha) \text { in case of high shock }
\end{aligned}
$$

Similarly, the cost equation of the firm in case of ijarah contract is defined below:

$$
Y_{t}^{i j a}=\varphi_{t} F_{t}^{e}
$$

This equation defines the profit received by the principal. Nevertheless, in case of default or damage to the leased asset that comes from lessee negligence, the agent may lose control of the asset.

\subsection{Determination of the Industrial Shock}

Based on Adda and Cooper (2002); Tauchen (1986), the two levels of shocks are determined by the following first-order autoregressive process, AR (1)

$$
z_{t+1}=\rho z_{t}+\varepsilon_{t+1}, \operatorname{var}\left(\varepsilon_{t+1}\right)=\sigma_{\varepsilon}^{2}, \text { where }|\rho|<1 \text {. }
$$

Where $\varepsilon_{t+1}$ is defined as the white noise and is distributed with mean zero and unit variance $\sigma_{\varepsilon}^{2}$. The parameter $\rho$ is the slope coefficient of the AR (1) process, which represents the persistence of the shock. According to Adda and Cooper (2002) and Stokey and Lucas (1989), the quality of the approximation remains good except when the parameter $\rho$ is very close to the unity. Even though, Tauchen (1986) indicated that the parameter $\rho$ must be less than 0.9 for highly persistence of the shock. Experimentations showed that when it is close to 0.9, the gap between consecutive shocks becomes very low. To discretize the AR (1) process, Tauchen (1986) assumed that the process stays within a bounded interval to be able to solve the problem. Specifically, the author considered that the shock can be approximated by a two-state Markov chain such that $Z$ can take on two values namely, $Z_{L^{\prime}} Z_{H}\left(Z_{L}<Z_{H}\right)$. Adda and Cooper (2002) assumed that the probability of the realization of the shocks can be determined by the following symmetric transition matrix: 


$$
\Pi=\left(\begin{array}{cc}
q & 1-q \\
1-q & q
\end{array}\right)
$$

The variables $Z_{L^{\prime}} Z_{H}$ and $q$ are selected by Adda and Cooper (2002) such that the process reproduces the conditional first and second order moments of the AR (1) process as follows:

First-order moment:

$$
\begin{aligned}
& q z_{L}+(1-q) z_{H}=\rho z_{L} \\
& (1-q) z_{L}+q z_{H}=\rho z_{H}
\end{aligned}
$$

Second-order moment:

$$
\begin{aligned}
& q z_{L}^{2}+(1-q) z_{H}^{2}-\left(\rho z_{L}\right)^{2}=\sigma_{\varepsilon}^{2} \\
& (1-q) z_{L}^{2}+q z_{H}^{2}-\left(\rho z_{H}\right)^{2}=\sigma_{\varepsilon}^{2}
\end{aligned}
$$

From the two equations of the first-order moment, we get $Z_{L}=-Z_{H^{\prime}}$ and $q=\frac{1+\rho}{2}$. Inserting these two results into the two equations of the second-order moment generates the following:

$$
\begin{aligned}
& z_{L}=\sqrt{\frac{\sigma_{\varepsilon}^{2}}{1-\rho^{2}}} \\
& z_{H}=-z_{L}=-\sqrt{\frac{\sigma_{\varepsilon}^{2}}{1-\rho^{2}}}
\end{aligned}
$$

However, one practice concern for the above approach is how to deal with negative values of the shock. More precisely, this means that the technology of the firm produces negative output, which does not hold from an economic perspective. To avoid this situation, it is required to transform the shock by taking its exponential form in order to ensure that all values of the shock are positive.

\subsection{Assumptions}

Assumption 1: the contract is optimal when it maximizes the value of the firm subject to the enforcement constraint for the agent and the participation constraint for the principal (Cooley et al., 2004)

Assumption 2: The principal can observe the information related to the firm only in case of bankruptcy. While it has always been a difference between declared and non-declared profit, the moral hazard problem occurs. Thus, problems of information asymmetry and moral hazard still exist and cannot be ignored, (Cooley et al., 2004).

Assumption 3: There is only one principal and one entrepreneur. Hart (1995) considered only one principal and one agent for contract arrangement because, in case of multiple agents and principles, it will be difficult to satisfy the incentives of compatible contracts and the optimality of the transaction.

Assumption 4: The principal and the agent are rational. The literature implies that economic agents are rational because they continuously aim to maximize their profit and minimize agency costs. 


\subsection{Model Determination based on Contracts}

\subsubsection{Murabahah Contract}

Although murabahah is a sale transaction contract, the bank purchases the assets in order to deliver it to the customer in exchange of pre-determined price. This price is increased by a pre-determined rate representing the profit of the financier. Nevertheless, when bankruptcy occurs, the agent loses the asset and the control shifts to the principal. Following the study of Cooley et al., (2004), the maximization program for the principal and the agent is defined as follows:

$$
\max V_{t}^{\text {mur }}\left(F_{t}^{e}, Z\right)=E_{t} \sum_{t=1}^{T} \beta^{t} X_{t}^{\text {mur }}
$$

Subject to

$$
\begin{aligned}
& E_{t} \sum_{t=1}^{T} \beta^{t} X_{t}^{\text {mur }} \geq D_{t}^{\text {mur }} \\
& D_{t}^{\text {mur }}=\overline{V_{t}^{\text {mur }}}-\kappa \\
& \overline{V_{t}^{\text {mur }}}=(1-p) V_{t}^{\text {mur }}\left(F_{t}^{e}, z_{L}\right)+p V_{t}^{\text {mur }}\left(F_{t}^{e}, z_{H}\right) \\
& E_{t} \sum_{t=1}^{T} \beta^{t} Y_{t}^{\text {mur }} \geq I_{0}
\end{aligned}
$$

Where equations (20), (21), and 24) define the value function of the firm, the enforcement constraint for the agent and the participation constraint for the principal respectively, when murabahah financing is used. In addition, equation (22) represents the default value for the agent whereas equation (22) refers to the value of searching a new project in case of murabahah contract.

\subsubsection{Ijarah Contract}

Considering the simplest form of ijarah as a contract of sale of the right to use an asset for a given period of time in exchange of a pre-determined rate, the maximization program for the principal and the agent are defined as given.

$$
\max V_{t}^{i j a}\left(F_{t}^{e}, Z\right)=E_{t} \sum_{t=1}^{T} \beta^{t} X_{t}^{i j a}
$$

Subject to

$$
\begin{aligned}
& E_{t} \sum_{t=1}^{T} \beta^{t} X_{t}^{i j a} \geq D_{t}^{i j a} \\
& D_{t}^{i j a}=\overline{V_{t}^{l j a}}-\kappa \\
& \overline{V_{t}^{l j a}}=(1-p) V_{t}^{i j a}\left(F_{t}^{e}, z_{L}\right)+p V_{t}^{i j a}\left(F_{t}^{e}, z_{H}\right) \\
& E_{t} \sum_{t=1}^{T} \beta^{t} Y_{t}^{i j a} \geq I_{0}
\end{aligned}
$$

Equation (25) defines the value of the firm, whereas equations (26) and (29) refer to the enforcement constraint for the agent and the participation constraint 
for the principal. Furthermore, equations (27) and (28) represent the default value for the entrepreneur and the value of searching a new project when ijarah financing is used.

\section{PARAMETERS CALIBRATION}

Tables 1 and 2 show the calibration of the state and control variables. Whilst a control variable corresponds to a variable that can be parameterized, a state variable is random and cannot be controlled.

Table 1.

Calibration of Control Variables

\begin{tabular}{|c|c|c|c|}
\hline Parameter & Label & Value & References \\
\hline$\delta$ & Depreciation rate & 0.0579 & (Cooley et al., 2004) \\
\hline$r_{f}$ & Risk-free rate & 0.0400 & (Cooley et al., 2004; Ahmed, 2002) \\
\hline$b$ & $\begin{array}{l}\text { Probability of } \\
\text { liquidation }\end{array}$ & 0.0500 & (Cooley et al., 2004) \\
\hline$l$ & Labor factor & 0.3300 & $\begin{array}{l}\text { (Cooley et al., 2004; Evans, 1987; } \\
\text { Atkeson and Kehoe, 2007) }\end{array}$ \\
\hline$\kappa$ & $\begin{array}{l}\text { Cost of } \\
\text { repudiation }\end{array}$ & 0.35 & (Cooley et al., 2004) \\
\hline$B$ & $\begin{array}{l}\text { Disutility from } \\
\text { working }\end{array}$ & 0.001 & (Cooley et al., 2004) \\
\hline$\epsilon$ & $\begin{array}{c}\text { The elasticity of } \\
\text { labor }\end{array}$ & 1.000 & (Cooley et al., 2004) \\
\hline$F=F^{e}$ & Invested funds & 100 & Adda and Copper (2002) \\
\hline
\end{tabular}

Table 1 shows all control variables used in our study. The same risk-free interest rate, $r_{f}$ was considered since the Islamic Inter-bank Rate (IIBR) and London Inter-bank Offered Rate (LIBOR) are significantly dependent, (Ben Amar, 2018). Although "Islamic banks pricing practices are likely to converge towards conventional ones" Ben Amar (2018, p. 7), the risk-free interest value calibrated by Cooley et al. (2004) is considered in this study for murabahah and ijarah. The probability of liquidation is set to $b=0.05$. Following the study of Cooley et al. (2004) this is consistent with the numbers reported in industry dynamics studies such as Evans (1987). The elasticity of labor is set to $\epsilon=1$, which is the value often used in business cycle studies, (Cooley et al., 2004). The parameter B is chosen by the authors, so that one third of available time is spent on working. The repudiation factor $\kappa$ is set 0.35 (Cooley et al. (2004), implying that the repudiation cost is 35 percent of the value of variable capital used by the firm. 
Table 2.

Calibration of State Variables

\begin{tabular}{lccc}
\hline Variable & Label & Value & References \\
\hline$\varphi$ & $\begin{array}{c}\text { Profit margin of the principal } \\
\text { in case of Ijarah }\end{array}$ & {$[0.25 ; 0.6]$} & $\begin{array}{c}\text { Shari'ah Advisory Council } \\
\text { (SAC Bank Negara Malaysia) }\end{array}$ \\
$g$ & $\begin{array}{c}\text { Profit margin of the principal } \\
\text { in case of murabahah }\end{array}$ & {$[0.2 ; 0.4]$} & $\begin{array}{c}\text { Shari'ah Advisory Council } \\
\text { (SAC Bank Negara Malaysia) }\end{array}$ \\
$\alpha$ & Market frictions & {$[0 ; 1]$} & Ahmed (2002) \\
\hline
\end{tabular}

Although this study examines debt-based contracts, it is recommended to provide theoretical evidence regarding the calibration of the state variables (Table 2). Dealing with debt-based contract, murabahah is a shari'a compatible mode of debt financing, which involves the sale of a commodity for a deferred price including mark-up or profit margin. Technically, murabahah is the mark-up or the profit margin provided to the purchaser of a certain specified asset, excluding monetary assets such as cash and receivables. In practice the profit margin varies according to credit risk factors, customer type, goods/assets and term of financing. Consequently, the literature supports this variation, while murabahah contract is separately concluded for each customer.

Considered the highest Shariah authority for Islamic finance in Malaysia, the Shari'ah Advisory Council of Bank Negara (SAC) puts stress on the pricing problem in case of murabahah ${ }^{15}$ by providing several explanations and examples. Admitting that the pricing of murabahah financing may take into consideration the London Inter-bank Offered Rate (LIBOR) as the base rate, the profit margin of the bank varies between $10 \%$ and $12 \%$ for a specific commodity, such as cars when the financing period is less or equal to three years. However, in case of firm's financing the profit margin may range between $20 \%$ and $40 \%$, and sometimes it exceeds $40 \%$ depending on the risk factor and the activity of the firm (SAC). Hypothetically, we consider that the profit margin for murabahah financing is ranged between $[20 \%$; $40 \%$ ] which are the minimum and the maximum profit margin that the principal may receive.

As far as the second form of Islamic debt-based contracts is concerned, the literature defines ijarah as the rent or the lease of a given asset. In practice, this contract comprises several principal features such as services, assets, ownership and usage rights and liabilities, lease period and rental amount. In its technical sense, $(\mathrm{SAC})^{16}$ indicated that the term ijarah has two different meanings. First, it can be defined as a hire contract to employ the services of a person with a predetermined wages service. Second, it can be considered as lease contract to transfer the usufruct of a particular property to another person in exchange for a rent. The most know form of ijarah is ijarah Muntahia bi al-Tamlik, defined as a lease

15. See Sharia'h Advisory Council, (2009). Draft of Sharia'h Parameter, Reference 1, Murabahah, for the approximation of the principal's profit margin in case of murabahah financing.

16. See Sharia'h Advisory Council, (2009). Draft of Sharia'h Parameter, Reference 2, Ijarah, for the approximation of the principal's profit margin in case of ijarah financing 
contract, which ends with the transfer of the leased asset to the lessee. However, the challenge was the establishment of a standard industry margin in order to specify the profit margin for the bank, and rental amount. Admitting that the profit margin in this context depends on the firm's activity sector, the risk factor, the maturity of the contract and the type of the asset, IFIs adopted London Interbank Offered Rate (LIBOR) or base Lending Rate (BLR) as a basis rate to calculate the profit margin and the rental amount by including the risk factor.

Assuming the risk factor is the most determinant component for bankers in this context, several illustrations are highlighted (SAC) in order to approximate the profit margin according to the activity of the firm. While the profit margin has almost been ranged between $40 \%$ and $50 \%$ according to (SAC), it was noticed that the manufacturing sector provides a margin average between [40\%; 60\%]. For retailers, bankers consider a margin between [25\%; 50\%], whereas the most used margin is $40 \%$. Dealing with distributors, IFIs adopted a margin around $[25 \% ; 50 \%]$, whereas they generally used $30 \%$ in this case. Based on the forgoing evidence it is noticeable that the profit margin varies proportionally according to the main activity of the firm, whereas the average adopted by IFIs in Malaysia ranges between $40 \%$ and $50 \%$ as stated above. Therefore, it is recommended in this theoretical study to consider the minimum and the maximum margin because we are dealing with a general context that does not consider the main activity of the firm. Hence, the profit margin for the principal in case of ijarah financing is equal to $\phi=[25 \% ; 60 \%]$.

\section{SIMULATION AND RESULTS}

This section aims to determine the optimal financing contract that maximizes the value of the firm subject to the enforcement constraint for the agent and the participation constraint for the principal regarding the variation of market frictions and the two levels of shocks. To do so, the simulation process linked to the maximization program is defined as follows.

- Firstly, it is required to calculate the two levels of shocks using the equations (17), (18), and (19), based on the study of Adda and Cooper (2002), Tauchen (1986), and Stokey and Lucas (1989).

- Secondly, we write the script of the objective function (equation (1)) after calculating the profit generated by the firm using the equations (6), (7) and (8).

- Thirdly, we build the code of both constraints using the equations (2), (3), (4) and (5) in a separate file.

- Fourthly, we use the optimization toolbox in Matlab to generate our results, by identifying the objective function, the constraints and the lower and upper bounds of the state variables.

- The optimization problem generates three plots, namely the current point, which indicates the simulated state variables, the current function demonstrating the optimal value of the firm, and the first-order optimality representing the value of firm's constraints violation) for each contract. We have to mention that Matlab's output generates negative values for the second and third plots. However, we interpret such simulated values as positive numbers (Table 3). 
Figure 1.

Murabahah (Low Shock)
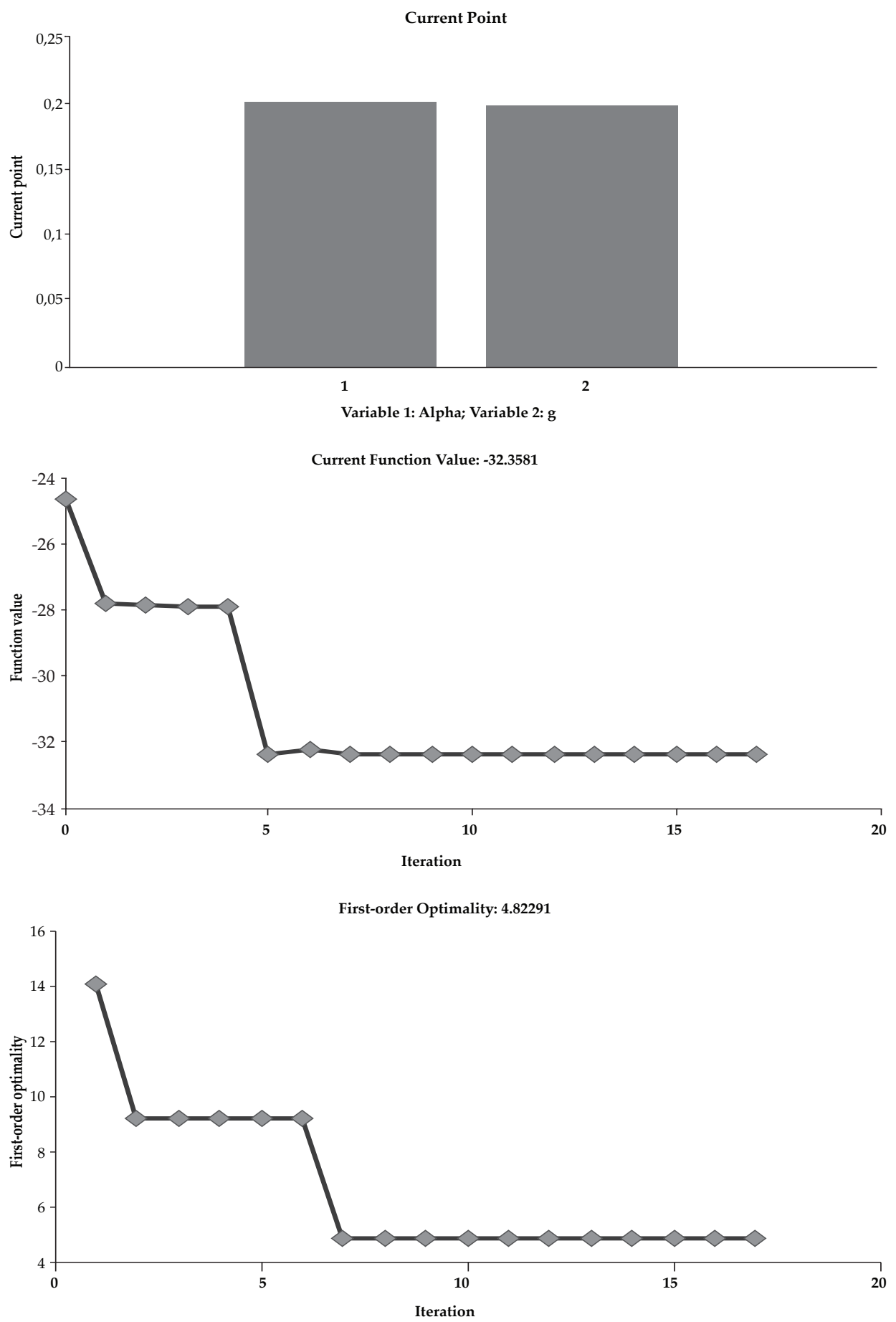
Figure 2.

Murabahah (High Shock)

Current Point

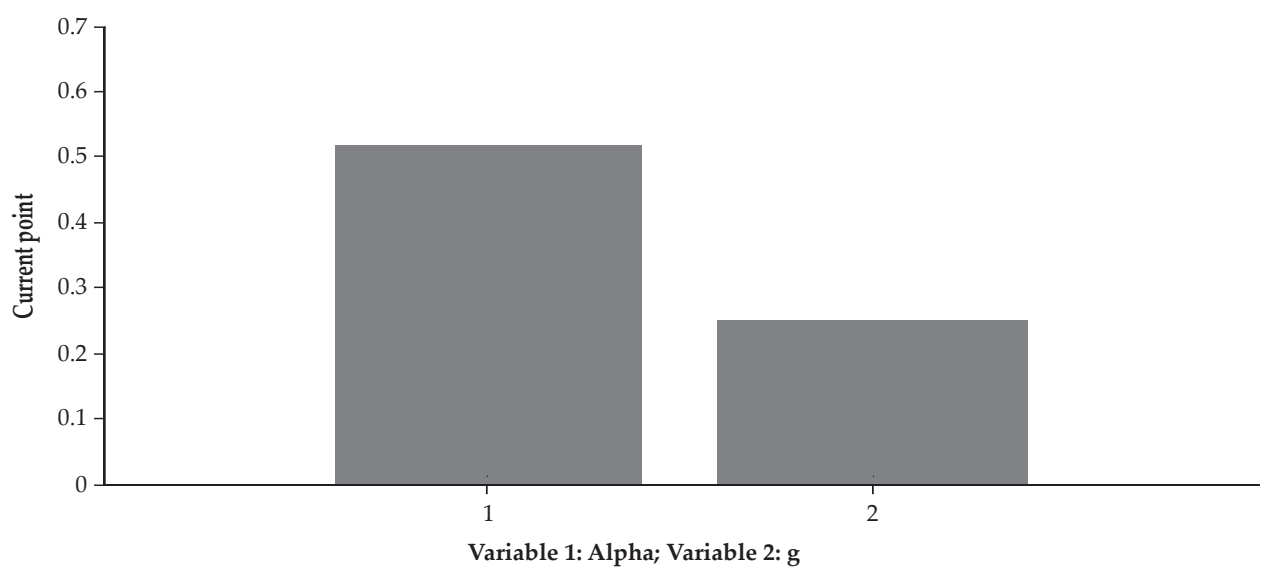

Current Function Value: -78.8896
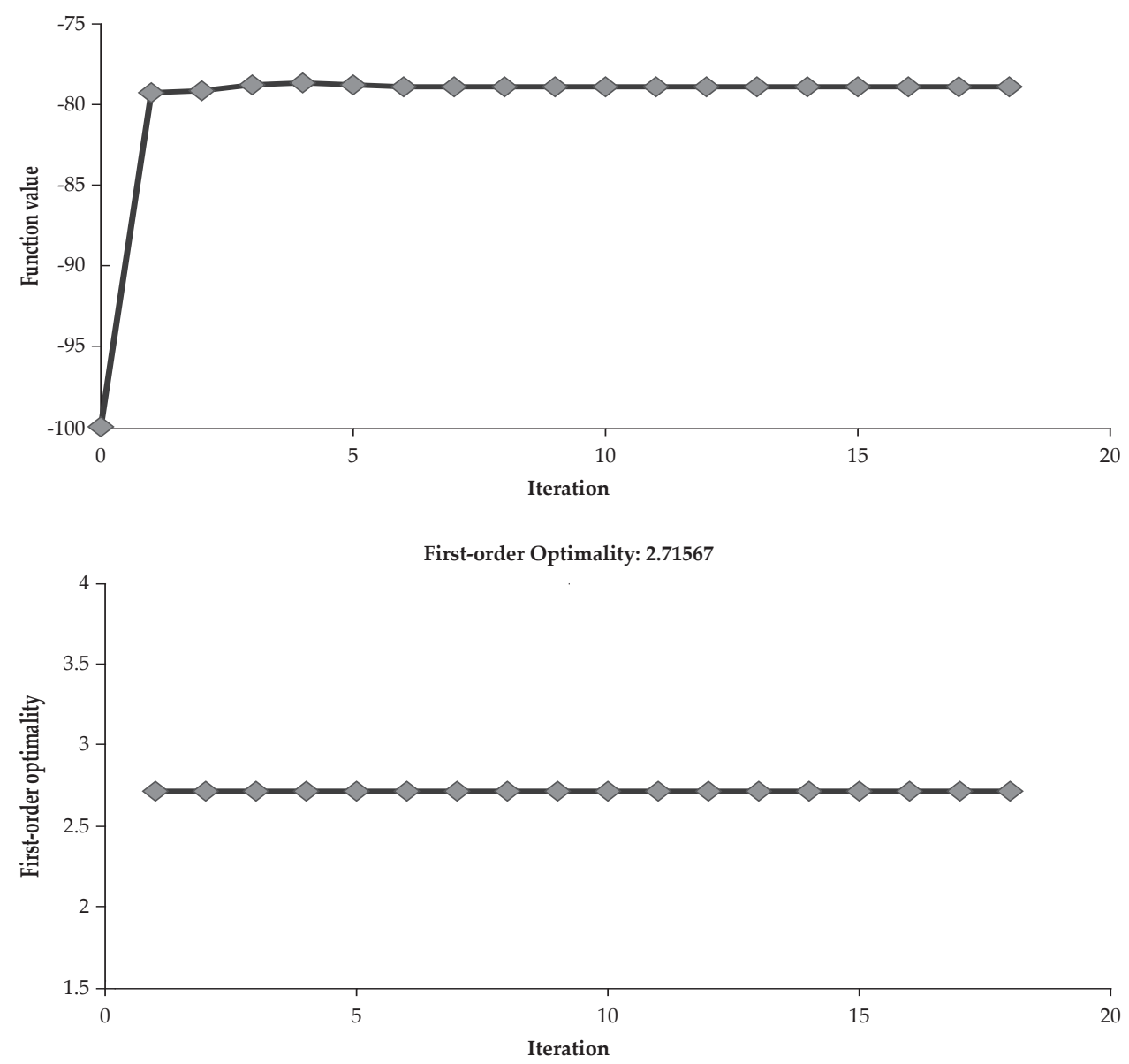
Figures 1 and 2 display the optimal values related to murabahah contract when the shock is low and high, after considering market frictions. The bar graphs of Figures 1 and 2 show the optimal values of the state variables namely, market frictions and the principal's profit margin. We notice that the simulated values of the parameters $\alpha$ and the profit margin $(g, \varphi)$ have been changed for both contracts when moving from the low shock to the high shock. The market frictions' parameter is optimally equally to 0.2 in case of low shock and 0.55 in case of high shock, respectively. Such a result indicates that when moving from the low shock to the high shock, market frictions tend to increase, implying that conflicts of interest among the principal and the agent may occur, which is in line with (Ebrahim and Sheikh, 2016).

Dealing with murabahah financing in case of low shock, the profit margin $g$, generated is equal to 0.2 , which is the optimal margin received by the principal. Furthermore, the optimal values of the firm subject to the enforcement constraint for the agent and the participation constraint for the principal are equal to 32.3581 and 78.8896 for the low and high shocks, respectively. As for the first-order optimality, the corresponding optimal values are equal to 4.8229 and 2.7156 for the low and high shocks, respectively. These simulation results indicate that when the shock is low the optimal profit margin allows the principal to handle the increase of market frictions, enabling her to get a firm's optimal value around 32.3581. In case of high shock, the simulated value of the state variable $g$ has experienced a significant change due to the increase of market frictions' parameter. Consequently, the optimal value of the firm increases to 78.8896, whereas the constraint violation becomes equal to 2.7156 .

For a given level of market frictions at $\alpha=0.55$, the increase of the optimal value from 32.3581 (in case of low shock) to 78.8896 (in case of high shock) means that the firm is able to maximize its value and aligns agents' interests. Admitting that moving from the low shock to the high shock engenders an increase of market frictions' parameter, the principal is compensated for this critical situation by having a higher profit margin rate. In case of high shock, the level of market frictions increases to reach 0.55 , implying that agents are more likely to cheat in order to satisfy her interest. However, the increase of the profit margin to 0.25 allows the principal to handle this level of information asymmetry.

Accordingly, the principal and the agent observe that their maximized value function increasing as a consequence of a higher level of the shock. It is for this reason that the simulated parameters regarding the market frictions and the profit margin have been changed after moving from the low shock to the high shock. In the same context, it is noticed that the increase of the shock alters the behavior of agents, which is mostly attributed to moral hazard. Consequently, the principal's profit margin slightly increases as a response of the higher risk taken in case of high shock. It is more attractive to enforce murabahah contract in the case of high shock because the optimal value of the firm is higher.

Similar findings are determined when ijarah financing is used. Table 3, Figure 3 , and Figure 4 display that the market frictions and the profit margin's simulated parameters are optimally equal to 0.2 and 0.25 , in the case of low shock, and for 0.55 and 0.3 , in the case of high shock, respectively. The simulated market frictions' parameters correspond to the same values in the case of murabahah, which is mostly 
Table 3.

Simulation Results

\begin{tabular}{lcccc}
\hline & \multicolumn{2}{c}{ Murabahah } & \multicolumn{2}{c}{ Ijarah } \\
\cline { 2 - 5 } & $\mathrm{Z}_{L}$ & $\mathrm{Z}_{H}$ & $\mathrm{Z}_{L}$ & $\mathrm{Z}_{H}$ \\
\hline Market frictions' parameter: & 0.2000 & 0.5500 & 0.2000 & 0.5500 \\
Principal's profit-margins: & 0.2000 & 0.2500 & 0.2500 & 0.3000 \\
Current optimal function value: & 32.3581 & 78.8896 & 33.7104 & 81.6103 \\
Constraints violation & 4.8229 & 2.7156 & 0.2697 & 2.7156 \\
\hline
\end{tabular}

attributed to the common debt-based agreements to both contracts. Nevertheless, the simulated value of the profit margin rates for the principal has been changed from 0.25 in the case of low shock to 0.3 , in the case of high shock. Compared to murabahah, the principal requests a higher profit margin in both cases of the shock when ijarah financing is used, whereas the variation of market frictions remains same for both contracts. This is attributed to the fact that the principal judges relevant to increase his profit margin in case of ijarah because murabahah is a simple contract of sale.

Regarding the optimized value of the firm, it is clear that it increases in the case of high shock as a response to the increased level of market frictions. Indeed, we notice that the optimal function value increased from 33.7104 to 81.6103 for ijarah in the cases of low and high shocks, respectively. The comparison between both contracts on the basis of the optimal value of the firm shows that the ijarah contract has the highest simulated value in both cases of low and high shocks, whereas the gap between this contract and the murabahah financing is very tight. This is indicative that the ijarah contract slightly dominates the murabahah contracts from the point of view of the principal and the agent who aim to maximize the value of the firm and align their interests. Therefore, we should claim that for a higher value of market frictions' parameter, the principal considers that it is more attractive to be engaged in a ijarah contract because (i) the optimized value of the firm is the highest between both contracts and (ii) her profit-margin ratio is higher to get compensated for the increased market frictions' value.

The examination of the simulated values that correspond to the first-order optimality indicates that, for the murabahah contract, it tends to decrease from a higher value (in case of a low shock) to a lower value (in case of high shock). However, for the ijarah, the first-order optimality value increases from a lower level (in case of low shock) to the higher level (in case of high shock). This is explained in terms of the enforcement and the participations' constraints corresponding to the maximization program. In addition, it is noticeable that the simulated values of the state variables have been changed for both contracts, depending on the two levels of shocks. This change can be explained by the selfish behavior of the agent who is more likely to cheat and hide a significant information about the project in order to maximize her profit when economic conditions do not improve. 

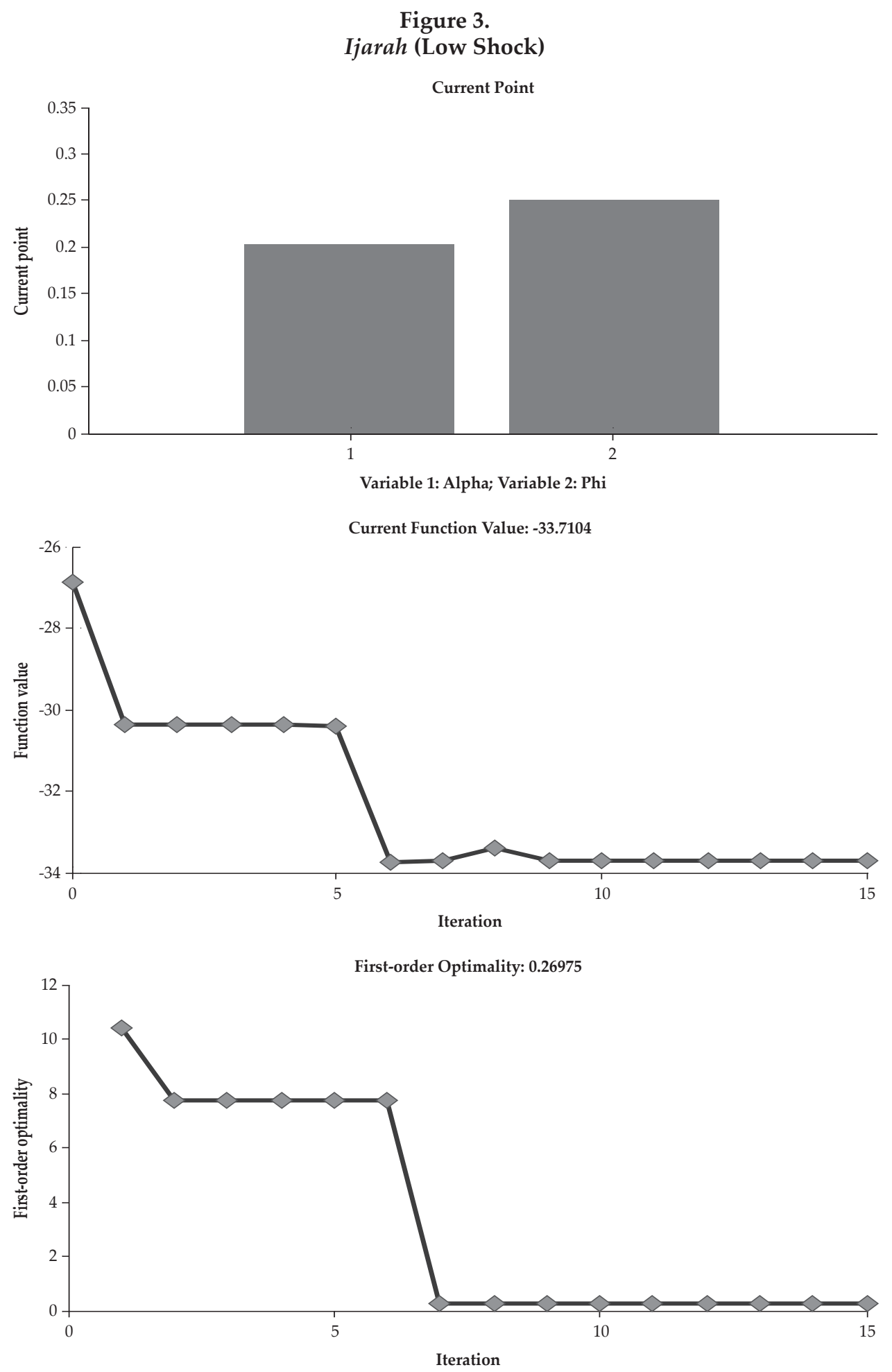
Figure 4.

Ijarah (High Shock)
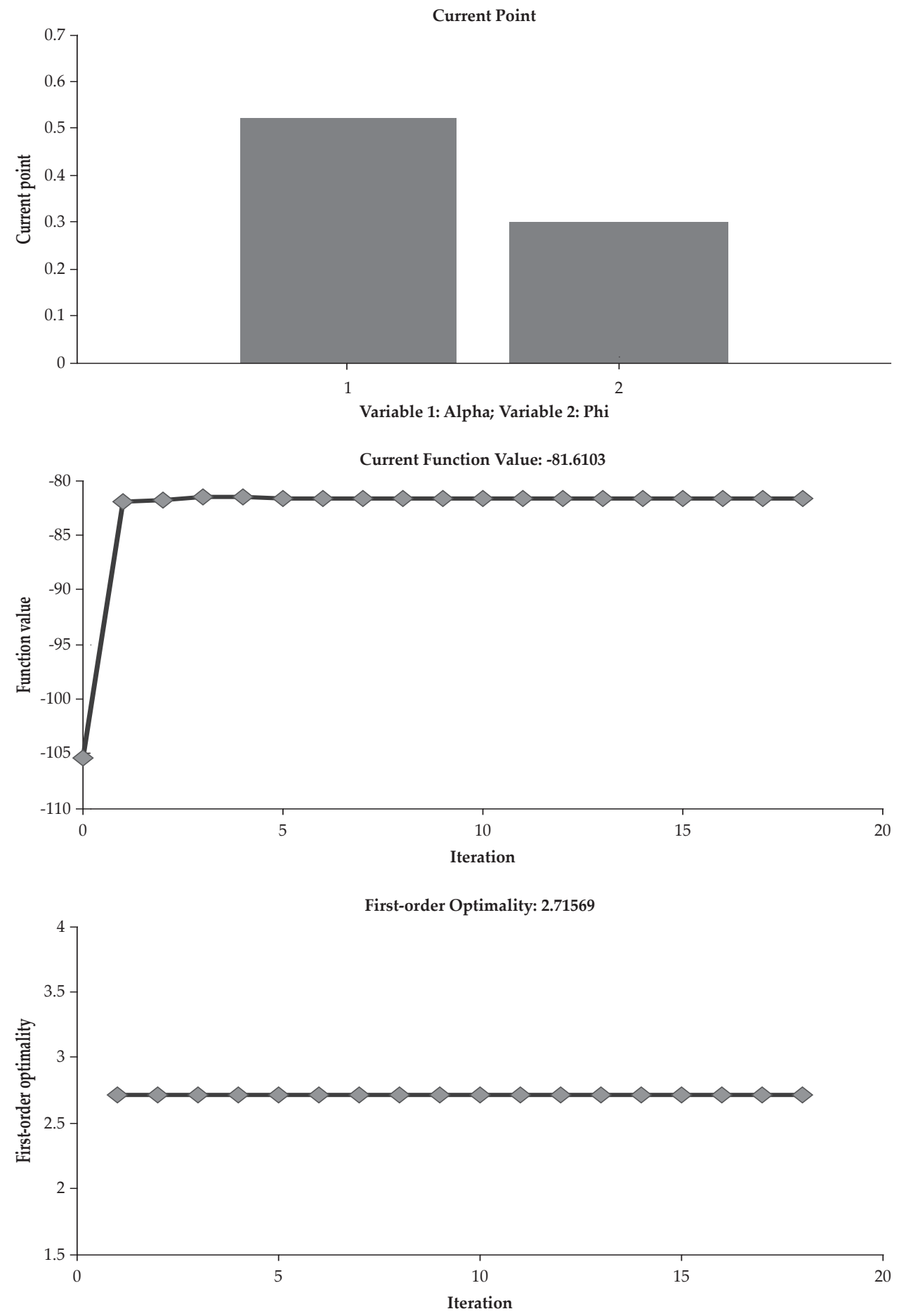


\section{CONCLUSION AND RECOMMENDATION}

Financing decision plays a crucial role for small firms and start-ups, especially when it comes to market frictions and the difficulties that they may face to get external funds and improve their business. Several financing instruments might be provided for agents whereas the selection of the optimal contract remains hard to achieve. This paper examines Islamic debt-based contract in order to yield further evidence regarding the excessive use of murabahah in Islamic finance instead of ijarah. Although this paper aims to determine the optimal contract that maximizes the value of the firm subject to the interests of the principal and the agent, the simulation results came out with relevant evidence. Findings reveal several insights regarding murabahah and ijarah contracts, based on the market frictions' parameter, the two levels of shocks and the optimal values generated for each contract.

Indeed, it was noticeable that the principal and the agent may bear the same level of market frictions when the shock is low and high. Admitting that the possibility of cheating is less likely to occur in case of low shock, our results show that the agent becomes more likely to hide significant information about the project when the shock is high for both contracts. Consequently, the profit margin's values for the principal increased when moving from the low shock to the high shock in order to compensate the considered higher risk. Consequently, the optimal values of the firm for both contracts increased in case of high shock, implying that the principal and the agent are able to maximize the value of the firm and align their interests in imperfect market.

In the same context, the simulation results show that the simulated optimal values for murabahah and ijarah are 32.3581 and 33.7104 in the case of low shock, and 78.8896 and 81.6103 in the case of high shock, respectively. This finding implies that ijarah allows the principal and the agent to get a higher value of the firm and mitigate conflicts of interest when the shock is low and high. In nutshell, ijarah contract slightly dominates murabahah contract when the shock is low and high. Although IFSB announced that murabahah is the most used contract in Islamic financing, this paper proves that the excessive use of this contract is not reasonable from the financial perspective for two main facts, unless it is supported by political and governmental authorities. First, ijarah dominates murabahah when the shock is low and high. Second, the gap between the optimal values of the firm in case of murabahah and ijarah for both levels of shocks is not significant.

Based on the simulation results, it is shown that the adoption of murabahah is related to regulations, rather than financial issues. Compared to the simplicity of murabahah, the legal issues addressed with respect to ijarah, such as the ownership of the asset constitute the main obstacle to promote this lease contract. Although ijarah suits certain projects, its role remains important within the economy in order to fulfill the needs of economic agents who are looking for financing. Our findings may motivate policy makers and regulators to re-think about ijarah financing. More precisely it may encourage economic players, scholars and monetary authorities to shed some light on the legal issues encountering ijarah in order to provide alternative solutions. 
Our paper has three main limits. First, our results were not compared to realdata because the latter are not available. Second, our paper is a general framework to determine the optimal contract that maximizes the value of the firm subject to agents' interest, but does not consider the firm and sectorial characteristics. Third, this study does not take account of the legal issues that the principal and the agent may face when ijarah and murabahah financings are used. However, it can be extended in various ways where, a qualitative analysis can be adopted to put stress on the principal-agent behavior in financial contracting. An adverse selection analysis can also be considered in order to determine the less risky contract for the principal when ijarah and murabahah financings are used. In addition, the examination of firm dynamics in the case of equity and debt financing can provide further arguments for economic agents regarding the value of the firm, the growth rate and the lifetime of the project when information is asymmetrically distributed.

\section{REFERENCES}

Adda, J. and Cooper, R. (2002). Dynamic economics: Quantitative methods and applications. USA: MIT press.

Abdullah, A. (2016). Examining us approvals of islamic financing products and the islamic theory of lawful profit. International Journal of Islamic and Middle Eastern Finance and Management, 9(4), 532-550.

Aghion, P., \& Bolton, P. (1997). A theory of trickle-down growth and development. Review of Economic Studies, 64(2), 151-172.

Aghion, P., Hart, O. \& Moore, J. (1992). The economics of bankruptcy reform. Journal of Law, Economics, and Organization, 8(3), 215-244.

Ahmed, H. (2002). Incentive-compatible profit-sharing contracts: A theoretical treatment. Edward Elgar Publishing Limited, Islamic Banking and Finance: New Perspective on Profit Sharing and Risk, 40-54.

Akerlof, G. A. (1970). The market for "lemons": Quality uncertainty and the market mechanism. The Quarterly Journal of Economics, 84(3), 488-500.

Albuquerque, R., \& Hopenhayn, H. (2004). Optimal lending contracts and firm dynamics. The Review of Economic Studies, 71(2), 285-315.

Al-Mubarak, T., \& Badri, A. (2015). Maqasid in risk management: An analysis of ijarah contract with special reference to Malaysia. International Institute of Advanced Islamic Studies (IAIS) Malaysia, Working paper.

Al-suwailem, S. (2003). Optimal sharing contracts. Work paper-Research $\mathcal{E}$ Development Al Rajhi Banking \& Investment Corp Presented, 1-57.

- - - . (1998). Venture capital: A potential model of musharakah. JKAU: Islamic Econ, 10(1), 3-20.

Aris, N. A., Othman, R., Azli, R.M., Arshad, R., Sahri, M., \& Yaakub, A.R. (2012). Islamic house financing: Comparison between bai' bithamin ajil (bba) and musharakah mutanaqisah (mm). African Journal of Business Management, 6(1), 266273.

Arrow, K. (1971). Essays in the theory of risk bearing. Markham Pub. Co

- - - . (1974). The limits of organization. New York: W.W. Norton

Atkeson, A. (1991). International lending with moral hazard and risk of repudiation. Econometrica, 59(4), 1069-1089. 
Bedoui, H., \& Mansour, W. (2015). Performance and maqasid al-Shari'ah's pentagon-shaped ethical measurement. Science and Engineering Ethics, 21(3), 555-576.

Ben Amar, A. (2018). An old wine in new shari'a compliant bottles? A time frequency wavelet analysis of the efficiency of monetary policy in dual financial systems. Economics Bulletin, 38(1), 558-564.

Chapra, I. U., Ahmed, A., Rehan, R., \& Hussain, F. (2018). Consumer's preference and awareness: Comparative analysis between conventional and islamic ijarah auto financing in Pakistan. Journal of Islamic Economics, 10(2), 389 - 402.

Chichti, J. \& Mansour, W. (2010-a). Is the investment-cash flow sensitivity still useful to gauge financing constrains? International Journal of Economic Policy in Emerging Economies, 3(1), 71-84.

Chichti, J. \& Mansour, W. (2010-b). Investment, marginal q, and net worth: Evidence from Europe. IUP Journal of Applied Economics, 9(3), 5-50.

Chichti, J. \& Mansour, W. (2012). Investment lumpiness and networth: Evidence from Europe. International Journal of Behavioural Accounting and Finance, 3(3), 145-162.

Coase, R. (1937). The nature of the firm. Economica, 4(16), 386-405.

Cooley, T., Marimon, R. \& Quadrini, V. (2004). Aggregate consequences of limited contract enforceability. Journal of Political Economy, 112(4), 817-847.

Dar, H., \& Presley, J. (2000). Lack of profit loss sharing in Islamic banking: Management and control imbalances. International Journal of Islamic Financial Services, 2, 9-12.

Ernawati, E. (2016). Risk of profit loss financing: The case of Indonesia. Al-Iqtishad: Jurnal Ilmu Ekonomi Syariah, (Journal of Islamic Economics), 8(1), 101-116.

Evans, D. (1987). Tests of alternative theories of firm growth. Journal of Political Economics, 95(1), 657-647.

Ebrahim, M. \& Sheikh, M. (2016). Debt instruments in Islamic finance: A critique. Arab Law Quarterly, 30(2), 185-198.

Farooq, O. (2007). Partnership, equity-financing and islamic finance: Whither profit-loss sharing?. International Association for Eslamic Economics, 11 (Special Issue), 67-88.

Fatwa Dewan Syari'ah Nasional No: 04/DSN-MUI/IV/2000 Tentang Murabahah.

Gale, D. \& Hellwing, M. (1985). Incentive-compatible debt contracts - the one period problem. Review of Economic Studies, 52(4), 647-663.

Hanif, M. (2016). Economic substance or legal form: An evaluation of Islamic finance practice. International Journal of Islamic and Middle Eastern Finance and Management, 9(2), 277-295.

Hart, O. (1989). An economist 's perspective on the theory of the firm. Columbia Law Review, 89(7), 1757-1774.

- - - (1995). Firms, contracts and financial structure, 1st Edition. OXFORD: Calaredon Press.

- - - (2003). Incomplete contracts and public ownership: Remarks and an application to public-private partnerships. The Economic Journal, 113(486), 6976.

- - -. (2017). Incomplete contracts and control. American Economic Review, 107(7), 1731-1752. 
Hart, O., \& Moore, J. (1994). A theory of debt based on the inalienability of human capital. The Quarterly Journal of Economics, 109(4), 841-879.

Hashmi, Omar A. (2009). Islamic home finance in the United States: Solution or deception? Howard Law Journal, 52(3), 709.

Islamic Financial Services Board (IFSB). (2018). Financing by Type of Shari'ah Compliant Contract. Retrieved from https://www.ifsb.org/psifi_02.php.

Jensen, M.C., \& Meckling, W.H. (1976). Theory of the firm: Managerial behavior, agency costs and ownership structure. Journal of Financial Economics, 3(4), 305360.

Khan, B., Khan, M., Shagufta, B., Ahmad, I., \& Ilyas, M. (2015). Comparison of islamic and conventional banking practices regarding house finance in Pakistan: A case of hazara decision. Academic Research International, 5(5), 251261.

Kehoe, T., \& Levine, D. (1993). Debt-constrained asset markets. The Review of Economic Studies, 60(4), 865-888.

Khong, Y., Cheng, L., \& Tan, K. (2018). A study on the level of acceptance towards the islamic home financing: Empirical study in Malaysia. Research in Economics and Management, 3(1), 45-67.

Lone, A., \& Quadir, A. (2017). Incentive structure of financing a project: An Islamic finance approach. International Journal of Economics and Financial Issues, 7(1), 87-91.

Maghrebi, N., \& Mirakhor, A. (2015). Risk sharing and shared prosperity in Islamic finance. Islamic Economic Studies, 23(2), 85-115.

Majdoub, J. \& Mansour, W. (2014). Islamic equity market integration and volatility spillover between emerging and US stock markets. North-American Journal of Economics and Finance, 29(3), 452-470.

Majdoub, J., Mansour, W., \& Arrak, I. (2018). Volatility spillover among equity indexes and crude oil prices: Evidence from islamic markets. Journal of King Abdulaziz University: Islamic Economics, 31(1), 27-45.

Majdoub, J., Mansour, W. \& Jouini, J. (2016). Market integration between conventional and islamic stock prices. North-American Journal of Economics and Finance, 37, 436-457.

Mansour, W. (2014). Information asymmetry and financing constraints in GCC. Journal of Economic Asymmetries, 11, 19-29.

Mansour, W., Ben Abdelhamid, M. \& Heshmati, A. (2015). Recursive profit and loss sharing. Journal of Risk, 17(6), 21-50.

Marcet, A., \& Marimon, R. (1992). Communication, commitment, and growth. Journal of Economic Theory, 58(2), 219-249.

Mehri, M. Jouaber, K. \& Hassan, M. (2017). Profit-sharing ratio as a screening device in venture capital. Edward Elgar Publishing, Handbook of Empirical Research on Islam and Economic Life, 579-601.

Muda, R. \& Ismail, A. (2010). Profit-loss sharing and value creation in Islamic banks. Journal of Business and Policy Research, 5(2), 262-281.

Muhammad, M. (2014). Critical analysis of some of the major internal hindrance factors in the application of musharakah financing by the islamic banks. International Journal of Education and Research, 2(9), 125-142. 
Nabi, S. (2012). Profit sharing, income inequality and capital accumulation. IRTI working paper, (21200).

Quintin, E. (2003). Limited enforcement and the organization of production. Journal of Macroeconomics, 30(3), 1222-1245.

Ross, S. (1973). The economic theory of agency: The principal's problem. The American Economic Review, 63(2), 134-39.

Sapuan, N. (2016). An evolution of mudarabah contract: A viewpoint from classical and contemporary islamic scholars. Procedia Economics and Finance, 35(2016), 349-358.

Sharia'h Advisory Council, (2009). Draft of Sharia'h Parameter, Reference 1, Murabahah, Bank Negara Malaysia.

Sharia'h Advisory Council, (2009). Draft of Sharia'h Parameter, Reference 2, Ijarah, Bank Negara Malaysia.

Shofawati, A. (2014). Murabahah financing in islamic banking: Case study in Indonesia. Proceedings of 5th Asia-Pacific Business Research Conference 17 - 18.

Smith, A. (1776). The Wealth of Nations.

Stokey, N. \& Lucas, R. (1989). Recursive methods in economic dynamics. USA: Harvard University Press

Tauchen, G. (1986). Finite state markov-chain approximations to univariate and vector autoregressions. Economics Letters, 20(2), 177-181.

Tirole, J. (1999). Incomplete contracts: Where do we stand?. Econometrica, 67(4), 74-81.

Wahla, A., Hasan, H., \& Ishaq Bhatti, M. (2018). Measures of customers' perception of car ijarah financing. Journal of Islamic Accounting and Business Research, 9(1), 2-16.

Williamson, O. (1979). Transaction-cost economics: the governance of contractual relations. The Journal of Law and Economics, 22(2), 233-261. 